\title{
Prevalence of Mild Cognitive Impairment in the Lothian Birth Cohort 1936
}

Miles Welstead ${ }^{\mathrm{a}} \mathrm{MSc}^{*}$

Michelle Luciano ${ }^{\mathrm{a}} \mathrm{PhD}$

Graciela Muniz-Terrera ${ }^{b} \mathrm{PhD}$

Adele M. Taylor ${ }^{\mathrm{a}} \mathrm{MA}$

Tom C. Russ ${ }^{a-c}$ PhD MRCPsych

a Lothian Birth Cohorts, Department of Psychology, University of Edinburgh, 7 George Square, Edinburgh, UK;

${ }^{b}$ Edinburgh Dementia Prevention, University of Edinburgh, BioCube 1, Edinburgh, UK;

c Alzheimer Scotland Dementia Research Centre, 7 George Square, University of Edinburgh, Edinburgh, UK

${ }^{*}$ Corresponding author

Miles Welstead, School of Philosophy, Psychology \& Language Sciences, 7 George Square, University of Edinburgh, United Kingdom, EH8 9JZ

Email: miles.welstead@ed.ac.uk

ORCID: 0000-0003-4615-2539

Conflicts of interest: The authors have no conflicts to declare.

Declarations of interest:_Age UK and MRC are involved in funding the recruitment and data collection for the Lothian Birth Cohort 1936. The sponsor had no role in the design, methods, analysis and preparation of paper.

Funding: LBC1936 data collection and MW's PhD scholarship is funded by the Disconnected Mind project (funded by Age UK [MR/M01311/1] and MRC [G1001245/96099]. No editorial service was provided

Availability of data and material: Data was obtained from the Lothian Birth Cohort 1936, more information can be found at https://www.lothianbirthcohort.ed.ac.uk/

Code availability: $\mathrm{R}$ script can be provided upon request 


\section{ABSTRACT \\ Background}

The Lothian Birth Cohort 1936 (LBC1936) is a highly-phenotyped longitudinal study of cognitive and brain ageing. Given its substantial clinical importance, we derived an indicator of mild cognitive impairment $(\mathrm{MCl})$ as well as amnestic and non-amnestic subtypes at three time points.

\section{Methods}

$\mathrm{MCl}$ status was derived at three waves of the LBC1936 at ages $76(n=567), 79(n=441)$, and 82 years ( $n=341)$. A general $\mathrm{MCl}$ category was derived as well as amnestic $\mathrm{MCl}(\mathrm{aMCl})$ and non-amnestic $\mathrm{MCl}$ (naMCl). A comparison was made between $\mathrm{MCl}$ derivations using normative data from the LBC1936 cohort versus the general UK population.

\section{Results}

$\mathrm{MCl}$ rates showed a proportional increase at each wave between 76 and 82 years from 15\% to $18 \%$. Rates of $\mathrm{MCl}$ subtypes also showed a proportional increase over time: $\mathrm{aMCl} 4 \%$ to $6 \%$; naMCl $12 \%$ to $16 \%$. Higher rates of $\mathrm{MCl}$ were found when using the LBC1936 normative data to derive $\mathrm{MCl}$ classification rather than UK-wide norms.

\section{Conclusions}

We found that $\mathrm{MCl}$ and $\mathrm{aMCl}$ rates in the $\mathrm{LBC1936}$ were consistent with previous research. However, naMCI rates were higher than expected. Future LBC1936 research should assess the predictive factors associated with $\mathrm{MCl}$ prevalence to validate previous findings and identify novel risk factors.

Keywords: $\mathrm{MCl}$; Cognitive ageing; Amnestic; Non-amnestic; Prevalence 
medRxiv preprint doi: https://doi.org/10.1101/2020.10.08.20209130; this version posted October 12, 2020. The copyright holder for this preprint (which was not certified by peer review) is the author/funder, who has granted medRxiv a license to display the preprint in perpetuity.

All rights reserved. No reuse allowed without permission.

\section{Background}

In conjunction with advancements in health and social care in the past century, life expectancy has improved dramatically and contributed to a rapidly increasing older population. ${ }^{1}$ A consequence of this demographic shift is the challenge we now face to care for a larger number of older adults with susceptibility to cognitive deterioration. ${ }^{2}$ Understanding how cognitive decline affects older people is imperative in order to design interventions to slow or delay decline and ensure individuals are on the healthiest ageing trajectory possible. ${ }^{3}$ Decline in memory is a key indicator of dementia, however it is common in older age, and differences between normal age-related decline and the early stages of dementia can be difficult to differentiate. ${ }^{4}$

The concept of mild cognitive impairment $(\mathrm{MCl})$ traces back many years but has gained particular traction over the past few decades. ${ }^{5}$ Petersen, Doody, Kurz, et al. ${ }^{6}$ popularised the concept as a distinct clinical condition and established a set of criteria based on memory changes without loss of ability to undertake normal activities. These criteria heavily influenced the way in which $\mathrm{MCl}$ was, and continues to be, identified in research and clinical settings. However, other researchers such as Dubois \& Albert ${ }^{7}$ disputed the notion of $\mathrm{MCl}$ as a distinct clinical entity, instead proposing it as a stage of severity for particular disorders. Accordingly, they proposed a 'prodromal Alzheimer's Disease' based upon subjective memory complaints with progressive onset, preserved ability to undertake activities of daily living, neuroimaging, and biomarker testing. Disagreement on how $\mathrm{MCl}$ should be conceptualised has led to multiple attempts at an international consensus. Winblad, Palmer, Kivipelto, et al. ${ }^{8}$ reached consensus that $\mathrm{MCl}$ criteria should assess whether an individual has a dementia diagnosis, whether their cognition has shown subjective and/or objective decline over time, and whether their activities of daily living are significantly affected - and, indeed, how this latter criterion is judged. This groundwork informed the most recent guidelines proposed by the National Institute on AgingAlzheimer's Association (NIA-AA) workgroups on diagnostic guidelines for Alzheimer's disease. ${ }^{9}$ These guidelines propose four criteria based on: 1 . Concern regarding a change in cognition, 2. Impairment in one or more cognitive domains, 3. Preservation of independence in functional abilities, 4. No diagnosis of dementia. In addition to identifying general $\mathrm{MCl}$, there has also been increased interest in identifying specific subtypes of $\mathrm{MCl}$ 
medRxiv preprint doi: https://doi.org/10.1101/2020.10.08.20209130; this version posted October 12, 2020. The copyright holder for this preprint (which was not certified by peer review) is the author/funder, who has granted medRxiv a license to display the preprint in perpetuity.

All rights reserved. No reuse allowed without permission.

that may precede certain types of dementia. For instance, amnestic $\mathrm{MCl}$ (aMCl) focuses solely on memory-related cognitive impairment, whereas non-amnestic $\mathrm{MCl}$ (naMCl) focusses on cognitive impairment in other domains such as processing speed, attention, and executive functions. ${ }^{10}$ Whilst $\mathrm{aMCl}$ is associated with a high risk of converting to Alzheimer's disease, naMCl is associated with other types of dementia such as diffuse Lewy body dementia. ${ }^{11}$ Identifying $\mathrm{MCl}$ in general as well as its subtypes will allow for improved knowledge on how early prevention strategies can identify individuals who are at high risk of cognitive decline and subsequent dementia. Here we use the NIA-AA guidelines to derive an identification of $\mathrm{MCl}$ and its subtypes using data from the Lothian Birth Cohort $1936 .{ }^{12,13}$ We hypothesise that $\mathrm{MCl}$ rates will be similar to those found in other older adult cohorts and that prevalence of all types of $\mathrm{MCl}$ will be higher in later data waves.

\section{Methods}

At Wave 1, the LBC1936 study consisted of 1091 participants, born in 1936 with a mean age of $69(\mathrm{SD}=0.89)$ years, mostly surviving members of the Scottish Mental Survey $1947 .{ }^{14}$ Wave 1 took place between 2004 and 2007, with follow-up waves approximately every three years thereafter at ages: $73(n=866), 76(n=697), 79(n=550)$, and 82 years $(n=431)$. More details on recruitment and testing procedures have been published previously. ${ }^{12,13,15}$ The LBC1936 study was conducted according to the Declaration of Helsinki guidelines. Ethical permission for the LBC1936 study protocol was obtained from the Multi-Centre Research Ethics Committee for Scotland (Wave 1: MREC/01/0/56), the Lothian Research Ethics Committee (Wave 1: LREC/2003/2/29), and the Scotland A Research Ethics Committee (Waves 2, 3, 4 \& 5: 07/MRE00/58). Written consent was obtained from participants at each of the waves.

Identification of $\mathrm{MCl}$

Using data previously collected in the LBC1936, an algorithm was created which identifies participants who fulfil the $\mathrm{MCl}$ criteria as outlined by the NIA-AA workgroups on diagnostic guidelines for Alzheimer's disease. ${ }^{9}$ Variables necessary to conduct $\mathrm{MCl}$ coding were 
medRxiv preprint doi: https://doi.org/10.1101/2020.10.08.20209130; this version posted October 12, 2020. The copyright holder for this preprint (which was not certified by peer review) is the author/funder, who has granted medRxiv a license to display the preprint in perpetuity.

All rights reserved. No reuse allowed without permission.

collected from Wave 3 (age 76) onwards. In order to be classified in the $\mathrm{MCl}$ category, participants must have shown met all four criteria reported below:

1. Concern regarding a change in cognition: Self-reported memory problems that are interfering with their life, as recorded in a questionnaire at each wave.

2. Impairment in one or more cognitive domains: Scores at least 1.5 SD below the mean on at least one cognitive domain (memory, executive function, attention, language, or visuospatial skills) AND either shows a decline from the previous wave to below the 10th percentile on one test, a decline from wave 1 to below the $20^{\text {th }}$ percentile on one test, or a decline from the previous wave to below the 20th percentile on two tests.

3. Preservation of independence in functional abilities: Scores at least 1.5 SD below the mean on the Townsend's Disability Scale overall score. ${ }^{16}$

4. No diagnosis of dementia: Does not self-report or have a formal diagnosis of dementia AND scores at least 24 on the Mini-Mental State Examination (MMSE). ${ }^{17}$

Cognitive domains were assessed using the following cognitive tests: Symbol Search, Digit Symbol Coding, Matrix Reasoning, Letter-Number Sequencing, and Block Design from the Wechsler Adult Intelligence Scale III (WAIS) and Logical Memory I \& II from the Wechsler Memory Scale III (WMS-III). ${ }^{18}$ A cut-off of $\geq 1.5$ SD below the mean or scoring below specific percentiles was used to indicate cognitive impairment. Two versions of the cognitive impairment criterion were conducted using the means and standard deviations of individual tests from (1) the LBC1936 sample at each wave and (2) a more representative UK sample provided by the WAIS-III-WMS-III technical manual. ${ }^{18}$ Preliminary comparisons showed that fewer participants were identified as having $\mathrm{MCl}$ using the general population norms, likely due to the higher rates of overall healthiness in the LBC1936. ${ }^{13}$ Therefore, the definition using UK normative data were used here as they were more reflective of the general population.

We also coded two subtypes of $\mathrm{MCl}$ : Amnestic $\mathrm{MCl}(\mathrm{aMCl})$ and Non-amnestic $\mathrm{MCl}$ (naMCl). Creation of these subtypes followed the same procedure as for the general $\mathrm{MCl}$, however aMCl was only identified if the participant showed impairment in the memory domain. Similarly, classification for naMCl was met if the participant showed impairment in 
cognitive domains other than memory (executive function, attention, language, or visuospatial skills).

\section{Covariates}

We examined the association between a range of covariates and $\mathrm{MCl}$ status. Covariates included: age, sex, years of education, age 11 cognitive function, body mass index (BMI; calculated in the standard way of $\mathrm{kg} / \mathrm{m}^{2}$ ), occupational social class (professional/managerial/skilled, non-manual/skilled manual or semiskilled/unskilled), APOE \&4 status (allele present/absent), self-reported history of cardiovascular disease, selfreported history of stroke, depression, and physical frailty level (not frail/pre-frail/frail). Physical frailty was derived using the Fried Phenotype guidelines ${ }^{19}$, for information on how this was calculated in LBC1936 see Welstead, Muniz-Terrera, Russ, et al. ${ }^{20}$. Depression was measured using the Hospital Anxiety and Depression scale (HADS). ${ }^{21}$ Age 11 cognitive function was based on LBC1936 participant's scores on the Moray House Test (MHT) at age $11^{22}$; for more detail see Taylor, Pattie, Deary ${ }^{13}$. To adjust for age in days at time of testing, MHT11 scores were residualised for age at 11 years.

\section{Statistical Analysis}

Three participants had been diagnosed with dementia before age 76 (wave 3) by the LBC1936 study doctor and were excluded, leaving 694 participants at that wave. Additionally, since a wide variety of variables were required in order to derive an $\mathrm{MCl}$ coding, missing data at each wave meant that some participants were excluded from analyses (wave $3 ; n=127$, wave $4 ; n=106$, wave $5 ; n=87$ ). Accordingly, $\mathrm{MCl}$ status was coded for 567 participants at wave 3 (age 76), 441 at wave 4 (age 79), and 341 at wave 5 (age 82). Descriptive analyses including number and percentages of people with $\mathrm{MCl}$ were used to characterise the study sample. Linear Model ANOVAs and Pearson's Chi-squared tests were used to assess characteristics associated with $\mathrm{MCl}$ and Non-MCl participants. All statistical analyses were conducted in $\mathrm{R}$ Version 3.6.1. ${ }^{23}$ 
medRxiv preprint doi: https://doi.org/10.1101/2020.10.08.20209130; this version posted October 12, 2020. The copyright holder for this preprint (which was not certified by peer review) is the author/funder, who has granted medRxiv a license to display the preprint in perpetuity.

All rights reserved. No reuse allowed without permission.

\section{Results}

Figure 1 show the rates of $\mathrm{MCl}$ in the LBC1936. There was an increase in people with $\mathrm{MCl}$ over time with $15 \%$ at wave $3(n=87 / 567), 17 \%$ at wave $4(n=77 / 441)$, and $18 \%$ at wave 5 ( $n=62 / 341$ ) having $\mathrm{MCl}$. As there were a substantial number of participants who withdrew from the study between baseline and final follow-up, we also looked at $\mathrm{MCl}$ rates for completers only, i.e. those who completed waves 3, 4, and 5. Results showed an overall proportional increase over follow-up with $14 \%$ of completers identified as having $\mathrm{MCl}$ at wave $3(n=38 / 271)$ and wave $4(n=38 / 271)$, and then a rise to $21 \%$ at wave $5(n=57 / 271)$.

\section{Figure 1: Comparisons of $\mathrm{MCl}$ rates in the Lothian Birth Cohort 1936 study across}

\section{waves using UK wide normative data}

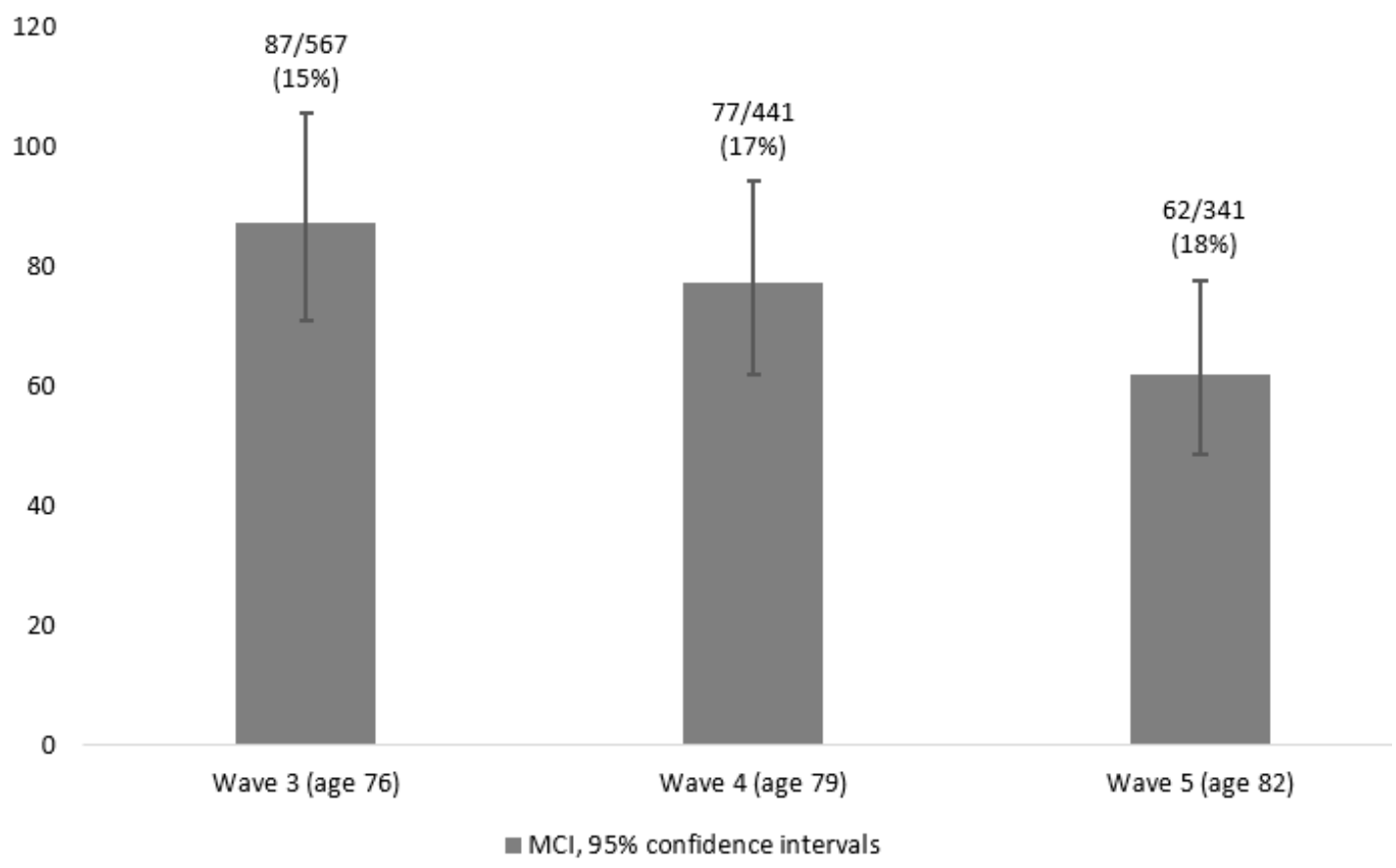

$\mathrm{MCl}$ rates did not differ significantly by sex at any of the waves. The only significant differences found indicated that higher rates of $\mathrm{MCl}$ were associated with APOE \&4 status at wave $3(p<0.001)$ and wave $5(p<0.05)$, and history of stroke at wave $3(p<0.01)$ and wave 5 $(p<0.05)$. Covariate differences according to $\mathrm{MCl}$ status are reported in Table 1. 
Table 1: Covariate descriptive statistics for participants with $\mathrm{MCl}$ present vs absent

\begin{tabular}{|c|c|c|c|c|c|c|c|c|c|}
\hline \multirow[b]{2}{*}{ Variables } & \multicolumn{3}{|c|}{ Wave 3} & \multicolumn{3}{|c|}{ Wave 4} & \multicolumn{3}{|c|}{ Wave 5} \\
\hline & $\begin{array}{l}\mathrm{MCl} \text { absent } \\
(\mathrm{N}=480)\end{array}$ & $\begin{array}{l}\text { MCl present } \\
(\mathrm{N}=87)\end{array}$ & $p$-value & $\begin{array}{l}\mathrm{MCl} \text { absent } \\
(\mathrm{N}=364)\end{array}$ & $\begin{array}{l}\mathrm{MCl} \text { present } \\
(\mathrm{N}=77)\end{array}$ & $p$-value & $\begin{array}{l}\mathrm{MCl} \text { absent } \\
(\mathrm{N}=279)\end{array}$ & $\begin{array}{l}\text { MCI present } \\
(\mathrm{N}=62)\end{array}$ & $p$-value \\
\hline Age at wave 3 , mean (SD) & $76.25(0.68)$ & $76.21(0.66)$ & $0.55^{1}$ & $76.23(0.68)$ & $76.13(0.69)$ & $0.24^{1}$ & $76.20(0.69)$ & $76.17(0.72)$ & $0.75^{1}$ \\
\hline Sex, $n(\%)$ & & & $0.07^{2}$ & & & $0.37^{2}$ & & & $0.05^{2}$ \\
\hline Male & $248(52 \%)$ & $54(62 \%)$ & & $183(50 \%)$ & $43(56 \%)$ & & $133(48 \%)$ & $38(61 \%)$ & \\
\hline Female & $232(48 \%)$ & $33(38 \%)$ & & $181(50 \%)$ & $34(44 \%)$ & & $146(52 \%)$ & $24(39 \%)$ & \\
\hline $\begin{array}{l}\text { Years of education, mean } \\
\text { (SD) }\end{array}$ & $10.81(1.13)$ & $10.76(1.16)$ & $0.70^{1}$ & $10.90(1.19)$ & $10.87(1.14)$ & $0.85^{1}$ & $10.91(1.17)$ & $11.10(1.17)$ & $0.25^{1}$ \\
\hline $\begin{array}{l}\text { Age } 11 \text { cognitive function, } \\
\text { mean (SD) }\end{array}$ & $\begin{array}{l}1.21(11.70) \\
29\end{array}$ & $1.30(11.28)$ & $0.95^{1}$ & $1.75(11.41)$ & $1.73(12.01)$ & $0.99^{1}$ & $2.30(11.24)$ & $2.34(10.91)$ & $0.98^{1}$ \\
\hline Missing data & & & & & & & & & \\
\hline Depressive symptoms, mean & & & $0.23^{1}$ & & & $0.07^{1}$ & & & $0.05^{1}$ \\
\hline (SD) & $2.68(2.20)$ & $3.00(2.13)$ & & $2.55(2.13)$ & $3.04(2.30)$ & & $2.42(1.95)$ & $2.97(2.04)$ & \\
\hline Missing data & 1 & 0 & & 3 & 0 & & 3 & 1 & \\
\hline $\mathrm{BMI}$, mean (SD) & $27.71(4.41)$ & $27.66(4.23)$ & $0.92^{1}$ & $27.53(4.35)$ & $27.85(4.25)$ & $0.55^{1}$ & $27.44(3.91)$ & $27.77(4.13)$ & $0.56^{1}$ \\
\hline Missing data & 2 & 0 & & 3 & 1 & & 3 & 1 & \\
\hline History of cardiovascular & & & $0.05^{2}$ & & & $0.63^{2}$ & & & $0.34^{2}$ \\
\hline No & $327(68 \%)$ & $50(58 \%)$ & & $240(67 \%)$ & $49(64 \%)$ & & $185(67 \%)$ & $37(61 \%)$ & \\
\hline Yes & $153(32 \%)$ & $37(42 \%)$ & & $121(33 \%)$ & $28(36 \%)$ & & $91(33 \%)$ & $24(39 \%)$ & \\
\hline Missing data & 0 & 0 & & 3 & 0 & & 3 & 1 & \\
\hline History of stroke, $n(\%)$ & & & $0.003^{2}$ & & & $0.71^{2}$ & & & $0.017^{2}$ \\
\hline No & $433(90 \%)$ & $69(79 \%)$ & & $323(89 \%)$ & $70(91 \%)$ & & $254(92 \%)$ & $50(82 \%)$ & \\
\hline Yes & $47(10 \%)$ & $18(21 \%)$ & & $38(11 \%)$ & $7(9 \%)$ & & $22(8 \%)$ & $11(18 \%)$ & \\
\hline Missing data & & & & 3 & 0 & & 3 & 1 & \\
\hline
\end{tabular}




\begin{tabular}{|c|c|c|c|c|c|c|c|c|c|}
\hline \multirow[b]{2}{*}{ Variables } & \multicolumn{3}{|c|}{ Wave 3} & \multicolumn{3}{|c|}{ Wave 4} & \multicolumn{3}{|c|}{ Wave 5} \\
\hline & $\begin{array}{l}\mathrm{MCl} \text { absent } \\
(\mathrm{N}=480)\end{array}$ & $\begin{array}{l}\text { MCl present } \\
(\mathrm{N}=87)\end{array}$ & $p$-value & $\begin{array}{l}\mathrm{MCl} \text { absent } \\
(\mathrm{N}=364)\end{array}$ & $\begin{array}{l}\mathrm{MCl} \text { present } \\
(\mathrm{N}=77)\end{array}$ & $p$-value & $\begin{array}{l}\mathrm{MCl} \text { absent } \\
(\mathrm{N}=279)\end{array}$ & $\begin{array}{l}\text { MCl present } \\
(\mathrm{N}=62)\end{array}$ & $p$-value \\
\hline Social class, $n(\%)$ & & & $0.364^{2}$ & & & $0.22^{2}$ & & & $0.85^{2}$ \\
\hline Professional & $98(21 \%)$ & $19(22 \%)$ & & $88(24 \%)$ & $16(21 \%)$ & & $68(25 \%)$ & $16(27 \%)$ & \\
\hline Managerial & $189(40 \%)$ & $35(41 \%)$ & & $136(38 \%)$ & $36(47 \%)$ & & $106(38 \%)$ & $24(41 \%)$ & \\
\hline Skilled non-manual & $102(21 \%)$ & $11(13 \%)$ & & $76(21 \%)$ & $10(13 \%)$ & & $62(23 \%)$ & $12(20 \%)$ & \\
\hline Skilled manual & $70(15 \%)$ & $18(21 \%)$ & & $50(14 \%)$ & $14(19 \%)$ & & $32(11 \%)$ & $7(12 \%)$ & \\
\hline Semiskilled/Unskilled & $16(3 \%)$ & $3(3 \%)$ & & $11(3 \%)$ & $0(0 \%)$ & & $8(3 \%)$ & $0(0 \%)$ & \\
\hline Missing data & 5 & 1 & & 3 & 1 & & 3 & 3 & \\
\hline APOE $\varepsilon 4$ status, $n(\%)$ & & & $<0.001^{2}$ & & & $0.22^{2}$ & & & $0.018^{2}$ \\
\hline Absent & $332(74 \%)$ & $47(55 \%)$ & & $241(70 \%)$ & $46(63 \%)$ & & $195(74 \%)$ & $34(59 \%)$ & \\
\hline Present & $118(26 \%)$ & $38(45 \%)$ & & $102(30 \%)$ & $27(37 \%)$ & & $68(26 \%)$ & $24(41 \%)$ & \\
\hline Missing data & 30 & 2 & & 21 & 4 & & 16 & 4 & \\
\hline Fried Phenotype Status, $n$ & & & $0.75^{2}$ & & & $0.36^{2}$ & & & $0.89^{2}$ \\
\hline Not Frail & $197(41 \%)$ & $33(38 \%)$ & & $160(45 \%)$ & $30(39 \%)$ & & $135(49 \%)$ & $29(47 \%)$ & \\
\hline Pre-Frail & $224(47 \%)$ & 41 (47\%) & & $164(45 \%)$ & 35 (45\%) & & $119(43 \%)$ & $26(43 \%)$ & \\
\hline Frail & $59(12 \%)$ & $13(15 \%)$ & & $37(10 \%)$ & $12(16 \%)$ & & $22(8 \%)$ & $6(10 \%)$ & \\
\hline Missing data & 0 & 0 & & 3 & 0 & & 3 & 1 & \\
\hline
\end{tabular}

${ }^{1}$ Linear Model ANOVA; ${ }^{2}$ Pearson's Chi-squared test 
medRxiv preprint doi: https://doi.org/10.1101/2020.10.08.20209130; this version posted October 12, 2020. The copyright holder for this preprint (which was not certified by peer review) is the author/funder, who has granted medRxiv a license to display the preprint in perpetuity.

All rights reserved. No reuse allowed without permission.

$\mathrm{MCl}$ subtypes

We also derived two subtypes of $\mathrm{MCl}$ : aMCl and naMCl. As reported in Figure 2, proportions of aMCl remained fairly low across follow-up from $4 \%$ at wave $3(n=24 / 604)$, to $4 \%$ at wave $4(n=21 / 484)$, and $6 \%$ at wave $5(n=24 / 376)$. Prevalence of naMCl was higher and showed a gradual proportional increase over follow-up from $12 \%$ at wave $3(n=73 / 609)$, to $14 \%$ at wave $4(n=63 / 466)$, and $16 \%$ at wave $5(n=56 / 361)$.

Figure 2: Comparisons of aMCl vs Non-aMCl rates in the Lothian Birth Cohort 1936 study across waves

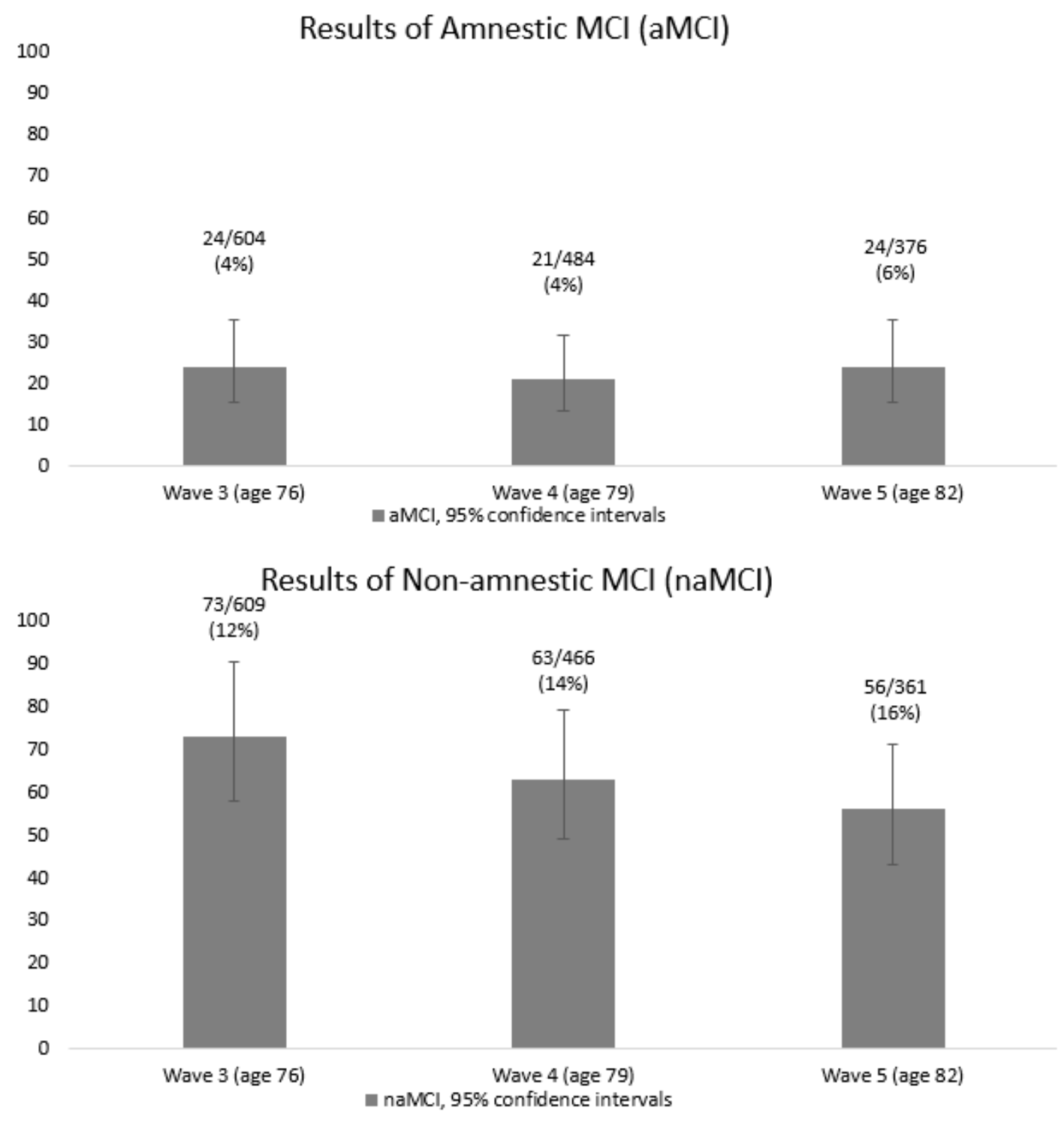

Normative data comparisons 
medRxiv preprint doi: https://doi.org/10.1101/2020.10.08.20209130; this version posted October 12, 2020. The copyright holder for this preprint (which was not certified by peer review) is the author/funder, who has granted medRxiv a license to display the preprint in perpetuity.

All rights reserved. No reuse allowed without permission.

We compared whether $\mathrm{MCl}$ rates were sensitive to the use of different normative data. Comparisons were made between $\mathrm{MCl}$ rates when using normative data based on the LBC1936 and a UK-wide sample to derive the identification of $\mathrm{MCl}$. As might be expected with a healthy cohort, at all waves there were higher proportions of $\mathrm{MCl}$ when using the LBC1936 norms compared to the UK based norms. Supplementary figure 1 reports $\mathrm{MCl}$ rates at each wave according to the LBC1936 normative data.

\section{Discussion}

We found $\mathrm{MCl}$ proportions in the LBC1936 study of $15 \%, 17 \%$, and $18 \%$ at ages $76,79,82$ years, respectively. Similar proportions were found when looking only at the individuals who attended all waves. $\mathrm{MCl}$ status at wave 3 and wave 5 (but not wave 4) was significantly associated with APOE $\varepsilon 4$ status and history of stroke. Proportions of people with aMCl were $4 \%$ at ages 76 and 79 years and $6 \%$ at 82 years, whereas rates of naMCl were higher but still showed an increase in proportions from $12 \%$ at age 76 years to $14 \%$ and $16 \%$ at 79 and 82 years, respectively.

\section{Comparison with other literature}

We observed higher rates of $\mathrm{MCl}$ in men, albeit not at a statistically significant level, a finding that is consistent with some previous research ${ }^{24,25}$, but not all. ${ }^{26,27}$ As discussed by Xue, Li, Liang, Chen ${ }^{27}$, sex differences in $\mathrm{MCl}$ research are inconsistent and may differ according to alternate methods of deriving $\mathrm{MCl}$. Importantly, the assessment of day-to-day function in men and women presents different challenges, and perhaps surprisingly, there were minimal significant associations between groups of individuals defined by key features. At two of the time points $A P O E \& 4$ status was associated with having $\mathrm{MCl}$, a finding which has been consistently found in previous $\mathrm{MCl}$ research and is also strongly linked to the risk of progression to dementia. ${ }^{28}$ The only other characteristic associated with $\mathrm{MCl}$ change was having a history of stroke, again somewhat unsurprising given the extensive evidence that stroke patients have higher risk for developing of $\mathrm{MCl}$ and dementia. ${ }^{29}$ The lack of significant association between these factors and $\mathrm{MCl}$ status at wave 4 is unexpected and not readily 
medRxiv preprint doi: https://doi.org/10.1101/2020.10.08.20209130; this version posted October 12, 2020. The copyright holder for this preprint (which was not certified by peer review) is the author/funder, who has granted medRxiv a license to display the preprint in perpetuity.

All rights reserved. No reuse allowed without permission.

explained. However, it may be related to attrition or other factors leading to sample differences at wave 4; the proportion of participants with $\mathrm{MCl}$ who had an APOE \&4 allele present or a history of stroke was lower at wave 4 than waves 3 or 5.

As expected, findings also showed an increase in proportion of participants with $\mathrm{MCl}$ at wave 5 compared to wave 3. The rates of $\mathrm{MCl}$ we find are consistent with previous research using the same $\mathrm{MCl}$ coding guidelines which reports an average prevalence of $14.8 \%$ for $70-75$ year olds. ${ }^{30}$ The rates of two subtypes of $\mathrm{MCl}-\mathrm{aMCl}$ and naMCl - were in partial agreement with previous literature. Some previous research ${ }^{10}$ has found rates of around $3-4 \%$ of both $\mathrm{aMCl}$ and $\mathrm{naMCl}$ in older populations, whilst others have found $11 \%$ for $\mathrm{aMCl}$ and $5 \%$ prevalence for naMCl. ${ }^{26}$ Thus, whilst the $\mathrm{aMCl}$ results are expected, the rates of naMCl in the $\mathrm{LBC1} 1936$ are higher than anticipated. Higher rates of naMCl than aMCl may indicate that participants of the LBC1936 are more prone to non-amnestic cognitive impairment in areas such as language, visual-spatial skills, attention, or executive functioning. Another possibility is that the salient memory problems associated with aMCl may make participants more likely to withdraw from the study, whereas the cognitive problems associated with naMCl (executive function, attention, language, or visuospatial skills) may more often go unnoticed by the participant. However, it is also important to note that making comparisons between our proportions of $\mathrm{aMCl}$ and naMCl cannot be done entirely accurately given that cases of missing data differed between them.

\section{Limitations and Strengths}

LBC1936's rates of high physical health and cognitive ability is well documented ${ }^{13,15}$, and highlights a limitation of this study: our sample is less representative of the general population who likely have higher rates of $\mathrm{MCl}$. An additional limitation that affects the accuracy of our results was that there was a relatively small number of participants who were identified as having a $\mathrm{MCl}$, which introduces an element of uncertainty into our results. For the participants who withdrew from the study, we did not have systematic information on their reason for dropping out. It is likely that at least some of these participants dropped out due to $\mathrm{MCl}$ or dementia, and accordingly we were unable to consider these cases in our 
medRxiv preprint doi: https://doi.org/10.1101/2020.10.08.20209130; this version posted October 12, 2020. The copyright holder for this preprint (which was not certified by peer review) is the author/funder, who has granted medRxiv a license to display the preprint in perpetuity.

All rights reserved. No reuse allowed without permission.

analyses. Related to this, other than three cases in which we had confirmation from the LBC1936 study doctor, we relied primarily on the self-reporting of dementia diagnoses for part of the $\mathrm{MCl}$ criteria. This could have introduced bias if additional participants had a dementia diagnosis but did not report it. Whilst self-reporting is used extensively in epidemiological studies and biases are usually insignificant ${ }^{31}$, given the nature of dementia, using these measures may have introduced inaccuracies. Current work is being undertaken in the LBC1936 to ascertain dementia status for every participant and so future research will be able to revisit this.

The strengths of this study are our use of data collected at multiple time points over the course of approximately six years in a well-characterised longitudinal cohort study. Using more than one time point gives us better insight into how $\mathrm{MCl}$ proportions change over time in the LBC1936. An additional strength is that we derived and compared an $\mathrm{MCl}$ coding using normative cognitive data from the LBC1936 sample and the UK wide norms. By doing so, we were able to assess the extent to which the LBC1936 data are representative of the wider population. As anticipated, $\mathrm{MCl}$ rates were higher at all waves when using the LBC1936 norms, presumably due to an overestimation caused by the higher rates of healthiness found in the LBC1936 when compared to the general population. Deriving $\mathrm{MCl}$ using the cohort's own normative data will cause the cognitive impairment cut-off points to be more lenient than using normative data from the UK population as we see in our results.

\section{Implications}

Our findings have added to the current literature by providing information on the prevalence of $\mathrm{MCl}$ in a prominent longitudinal cohort study, reinforcing findings found in similar cohorts. The identification of individuals with $\mathrm{MCl}$ in the LBC1936 and their comparison with findings in similar cohorts provides opportunities for future research to further explore $\mathrm{MCl}$ in this cohort. In particular, utilising the wealth of longitudinal data in the LBC1936 could prove insightful. MCI has been shown to be relatively fluid over time with both declines and reversions being common ${ }^{32-34}$. Accordingly, understanding this fluidity and the predictive factors associated with $\mathrm{MCl}$ change will be insightful for future 
medRxiv preprint doi: https://doi.org/10.1101/2020.10.08.20209130; this version posted October 12, 2020. The copyright holder for this preprint (which was not certified by peer review) is the author/funder, who has granted medRxiv a license to display the preprint in perpetuity.

All rights reserved. No reuse allowed without permission.

interventions and prevention strategies that aim to lower the risk of $\mathrm{MCl}$ developing and progressing.

\section{Conclusion}

This study is largely consistent with previous research, finding $\mathrm{MCl}$ rates of $15 \%$ to $18 \%$ in the LBC1936 at ages 76 to 82 . When considering subtypes of $\mathrm{MCl}$, non-amnestic $\mathrm{MCl}$ is more likely to affect participants than amnestic $\mathrm{MCl}$ indicating that perhaps this population is more prone to cognitive decline in non-amnestic cognitive domains. These results help highlight the prevalence of $\mathrm{MCl}$ in the LBC1936 and allow for future studies to explore cognitive trajectories over time and the predictive factors which may increase the risk of developing $\mathrm{MCl}$. 


\section{References}

1. Buckinx F, Rolland $Y$, Reginster J-Y, Ricour $C$, Petermans J, Bruyère $O$. Burden of frailty in the elderly population: perspectives for a public health challenge. Archives of Public Health. 2015;73(1):19.

2. Pankratz VS, Roberts RO, Mielke MM, et al. Predicting the risk of mild cognitive impairment in the Mayo Clinic Study of Aging. Neurology. 2015;84(14):1433-1442.

3. Robertson DA, Savva GM, Kenny RA. Frailty and cognitive impairment-a review of the evidence and causal mechanisms. Ageing research reviews. 2013;12(4):840-851.

4. Lo RY. The borderland between normal aging and dementia. Tzu-Chi Medical Journal. 2017;29(2):65.

5. Heinik J. VA Kral and the origins of benign senescent forgetfulness and mild cognitive impairment. International psychogeriatrics. 2010;22(3):395.

6. Petersen RC, Doody R, Kurz A, et al. Current concepts in mild cognitive impairment. Archives of neurology. 2001;58(12):1985-1992.

7. Dubois B, Albert ML. Amnestic MCl or prodromal Alzheimer's disease? The Lancet Neurology. 2004;3(4):246-248.

8. Winblad B, Palmer K, Kivipelto M, et al. Mild cognitive impairment-beyond controversies, towards a consensus: report of the International Working Group on Mild Cognitive Impairment. Journal of internal medicine. 2004;256(3):240-246.

9. Albert MS, DeKosky ST, Dickson D, et al. The diagnosis of mild cognitive impairment due to Alzheimer's disease: recommendations from the National Institute on Aging-Alzheimer's Association workgroups on diagnostic guidelines for Alzheimer's disease. Alzheimer's \& dementia. 2011;7(3):270-279.

10. Katz MJ, Lipton RB, Hall CB, et al. Age and sex specific prevalence and incidence of mild cognitive impairment, dementia and Alzheimer's dementia in blacks and whites: A report from the Einstein Aging Study. Alzheimer disease and associated disorders. 2012;26(4):335. 
11. Csukly $\mathrm{G}$, Sirály $\mathrm{E}$, Fodor Z, et al. The differentiation of amnestic type $\mathrm{MCl}$ from the nonamnestic types by structural MRI. Frontiers in aging neuroscience. 2016;8:52.

12. Deary IJ, Gow AJ, Taylor MD, et al. The Lothian Birth Cohort 1936: a study to examine influences on cognitive ageing from age 11 to age 70 and beyond. BMC geriatrics. $2007 ; 7(1): 28$

13. Taylor AM, Pattie A, Deary IJ. Cohort profile update: the Lothian Birth Cohorts of 1921 and 1936. International journal of epidemiology. 2018;47(4):1042-1042r.

14. Deary IJ, Whalley U, Starr JM. A lifetime of intelligence: Follow-up studies of the Scottish mental surveys of 1932 and 1947. American Psychological Association; 2009.

15. Deary IJ, Gow AJ, Pattie A, Starr JM. Cohort profile: the Lothian Birth Cohorts of 1921 and 1936. International journal of epidemiology. 2012;41(6):1576-1584.

16. Townsend P. Poverty in the United Kingdom: a survey of household resources and standards of living. Univ of California Press; 1979.

17. Folstein MF, Folstein SE, McHugh PR. "Mini-mental state": a practical method for grading the cognitive state of patients for the clinician. Journal of psychiatric research. 1975;12(3):189198.

18. Psychological Corporation. WAIS-III/WMS-III Technical Manual. 1997.

19. Fried LP, Tangen CM, Walston J, et al. Frailty in older adults: evidence for a phenotype. The Journals of Gerontology Series A: Biological Sciences and Medical Sciences. 2001;56(3):M146M157.

20. Welstead M, Muniz-Terrera G, Russ TC, et al. Inflammation as a risk factor for the development of frailty in the Lothian Birth Cohort 1936. Experimental Gerontology. 2020:111055.

21. Zigmond AS, Snaith RP. The hospital anxiety and depression scale. Acta psychiatrica scandinavica. 1983;67(6):361-370. 
22. Education SCfRi. The intelligence of Scottish children: A national survey of an age-group. Vol 5: London: University of London Press; 1933.

23. R Core Team. R: A Language and Environment for Statistical Computing. dim (ca533). 2018;1(1358):34.

24. Juarez-Cedillo T, Sanchez-Arenas R, Sanchez-Garcia S, et al. Prevalence of mild cognitive impairment and its subtypes in the Mexican population. Dementia and geriatric cognitive disorders. 2012;34(5-6):271-281.

25. Hänninen $T$, Hallikainen $M$, Tuomainen $S$, Vanhanen $M$, Soininen $H$. Prevalence of mild cognitive impairment: a population-based study in elderly subjects. Acta Neurologica Scandinavica. 2002;106(3):148-154.

26. Petersen RC, Roberts RO, Knopman DS, et al. Prevalence of mild cognitive impairment is higher in men: The Mayo Clinic Study of Aging. Neurology. 2010;75(10):889-897.

27. Xue J, Li J, Liang J, Chen S. The prevalence of mild cognitive impairment in China: a systematic review. Aging and disease. 2018;9(4):706.

28. Qian J, Wolters FJ, Beiser A, et al. APOE-related risk of mild cognitive impairment and dementia for prevention trials: an analysis of four cohorts. PLOS medicine.

2017;14(3):e1002254

29. Al-Qazzaz NK, Ali SH, Ahmad SA, Islam S, Mohamad K. Cognitive impairment and memory dysfunction after a stroke diagnosis: a post-stroke memory assessment. Neuropsychiatric disease and treatment. 2014;10:1677.

30. Petersen RC, Lopez O, Armstrong MJ, et al. Practice guideline update summary: Mild cognitive impairment: Report of the Guideline Development, Dissemination, and Implementation Subcommittee of the American Academy of Neurology. Neurology. 2018;90(3):126-135.

31. Kriegsman DM, Penninx BW, Van Eijk JTM, Boeke AJP, Deeg DJ. Self-reports and general practitioner information on the presence of chronic diseases in community dwelling elderly: 
medRxiv preprint doi: https://doi.org/10.1101/2020.10.08.20209130; this version posted October 12, 2020. The copyright holder for this preprint (which was not certified by peer review) is the author/funder, who has granted medRxiv a license to display the preprint in perpetuity.

All rights reserved. No reuse allowed without permission.

a study on the accuracy of patients' self-reports and on determinants of inaccuracy. Journal of clinical epidemiology. 1996;49(12):1407-1417.

32. Overton M, Pihlsgård M, Elmståhl S. Diagnostic Stability of Mild Cognitive Impairment, and Predictors of Reversion to Normal Cognitive Functioning. Dementia and Geriatric Cognitive Disorders. 2019;48(5-6):317-329.

33. Pandya SY, Clem MA, Silva LM, Woon FL. Does mild cognitive impairment always lead to dementia? A review. Journal of the neurological sciences. 2016;369:57-62.

34. Pandya SY, Lacritz LH, Weiner MF, Deschner M, Woon FL. Predictors of reversion from mild cognitive impairment to normal cognition. Dementia and geriatric cognitive disorders.

2017;43(3-4):204-214. 